\title{
USING POINT COUNTERPOINT METHOD TO IMPROVE SPEAKING ABILITY OF GERMAN LANGUAGE STUDENTS
}

\section{AT PATTIMURA UNIVERSITY}

\author{
H. Serpara ${ }^{1,2+}$, K. Karuna $^{1,2}$, Maria M. Nikijuluw ${ }^{1,2}$ \\ ${ }^{1}$ Faculty of Education and Teacher Training (FKIP), Pattimura University (UNPATTI), \\ Jl. Ir. M. Putuhena, Poka, Ambon, Indonesia 97233 \\ ${ }^{2}$ Language Laboratory Center, Pattimura University (UNPATTI), \\ Jl. Ir. M. Putuhena, Poka, Ambon, Indonesia 97233
}

Received : December 1, 2019

Revised : December 12, 2019

Published : December 16, 2019

Copyright @ All rights are reserved by H. Serpara, K. Karuna, and Maria M. Nikijuluw

Corresponding author: ${ }^{+}$Email: ikaserpara@yahoo.de 
This research is a classroom action research, which carried out to describe the development of students' speaking abilities as the effect of using the point counterpoint method. This research has been carried out in semester 5 (five) in academic year 2019/2020. The population of this study is the students of the German Language Study Program, while the selected sample is the 5th semester students in total 30 people. The procedure of this research was carried out in cycles, starting from planning, observation and reflection Research instruments are test and non-test. The results of cycle 1 indicate that students have not yet reached a minimum score or passing grade, on average score of 58.93. The results of the second cycle test show that results increased, namely on average score of 72.5. Overall, the results of this study indicate that using a point counterpoint method can improve students' speaking abilities, especially in creative thinking and argumentation. Thus, using this method in teaching is useful to support the achievement of speaking competency at a B1-GER level.

Keywords: Speaking Ability, Point Counterpoint Method, Creative thinking, Argumentation.

\section{ARTICLES}

\section{Introduction}

In the language learning [1-19] there are four skills, namely listening, speaking, reading and writing skill. Reading and listening skills are usually described as a receptive, because they do not produce speech or words, but instead only receive and process information internally, so that it is not visible. Further, it is described as a cognitive process [1]. While writing and speaking skills are categorized as active, productive linguistic skills. Specifically about speaking as a productive skill, it requires an extra
The invented contribution: The discovery of speaking ability improvement as large as $\sim 72 \%$ of German students particularly in the parts of creative thinking and argumentation.

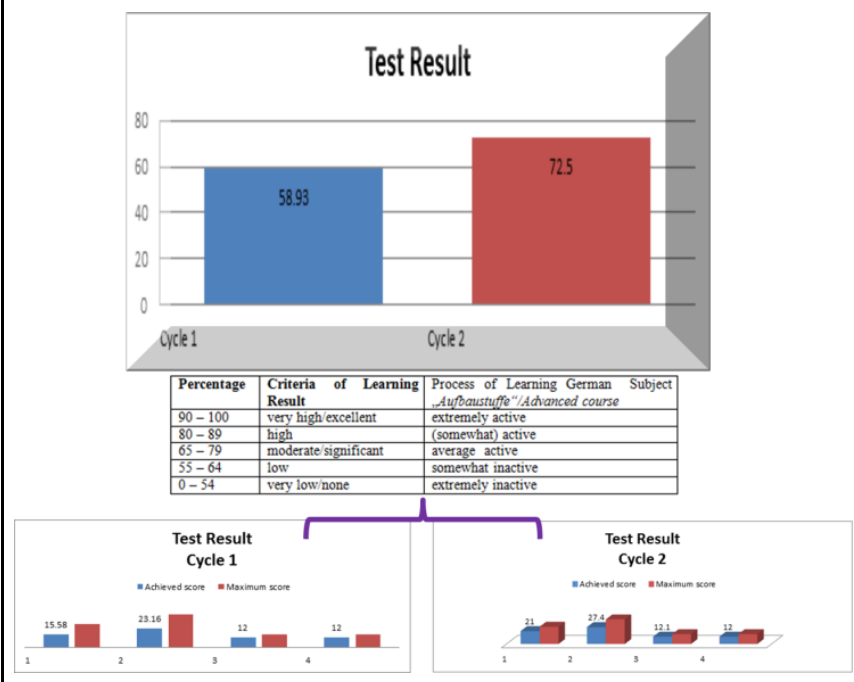

attention, because it has a greater psychological burden than other skills, for instance if speaking in front of audiences. Therefore, learning to speak must be well prepared. Related to this case, the German Language Study Program has tried to determine the allocation of sufficient time for the German linguistic courses, which are given for 4 semesters with each of the two credits, as well as improvement the national standard of curriculum based on the Indonesian National Qualification Framework, included the advanced level course. This course has aim to improve the students' language competencies, which it has six credit points. The determination of six credit points has implications for the allocation of longer time for the course, so that 
students and lecturers are expected to have sufficient time to study, understand, and then use the German language learned. The facts show that there was development of students related to the receptive language skills such as reading and listening. While productive skills such as speaking and writing, especially argumentative writing are still lacking. Moreover, the advanced level lecturer team observed that the students have also problems in expressing opinions verbally, both in terms of language and the structure of information and argumentation. Students could not express their opinions freely and still focused on memorized utterances without regard to the context. This has happened due to the limitations in exploring their potential through critical and comprehensive thinking. A hypothesis toward that problem is caused by the way that lecturers doing teaching based on the format of language learning tasks, which used only from the text book. This brief description describes two things that it can be understood as the cause and effect. On the one hand, students have limitations in developing their way of thinking, especially in speaking by using German. On the other hand, the methods and training techniques used, it has not been able to encourage students to develop their ways of thinking critically and comprehensively. Even this method is ultimately counterproductive when students are asked to complete exam assignments that require higher order thinking skills (HOTS). Therefore, we need the right way that can be used to overcome these problems, which is using the point counterpoint method, in accordance with speaking ability of German students at Pattimura University.
The use of the point counterpoint method is believed that it has advantages in improving students' speaking abilities. In essence, this method is directed to increase the student's speaking ability through discussion activities in the debate format. Through a debate the students will be encouraged to analyze the problem or issues being debated and then communicate the results of the analysis with critical and logical arguments. The application of this method is also a support for government policy or direction towards the need for higher-level thinking skills (HOTS) which must be trained from an early learning phase.

Based on the above considerations, this research applied the point counterpoint method in accordance with the Classroom Action Research (CAR) format. Further, the use of CAR is based on the consideration that the method must be adapted to the real conditions of students, both in language learning and in the development of the thinking way, so that it needs to be followed in cycles. In addition, if necessary, the improvements and adjustments should be conducted periodically in order to obtain one effective procedure.

\subsection{The Essence of Speaking Ability}

Speaking ability refers to language competence or in German "Sprachkompetenz". From the linguistic aspect, language competence is the use of language, if someone has more than one language. While competence itself can be interpreted as cognitive abilities and skills through something that has been learned and therefore it can solve different problems. Further, the use of language can also be interpreted as a term, which related to skills and reflection (see Weinert, 2001 in Khan 
2018: 55-56) in Ref. [2]. While, the term used in this study refers to ability to speak. In language learning, speaking ability is very important in communication process with others through using words, terms, expressions that students learned in the class. In addition, the ability to speak is related to the ability to listen and understand texts or questions. Related to learning a foreign language, listening ability is the initial ability that determines, whether students can respond a question or communicate back. In other word, after hearing something, for example in the form of text, students must be able to understand and then answer or argue that. If the ability to listen and understand texts, or questions in German are lacking, students may not be able to respond to the asked questions.

Furthermore, the language proficiency course syllabus, especially in the integration course of advance level mastery of language skills. It is focused on the ability of students to understand German utterances with discussion topics such as about the campus life, travelling and environment. In general, it can be said that the subject like "speaking class" is intended to improve the quality standards of higher education, including the academic quality of students in the field of German language teaching, especially a good communication skill. In addition, the communication in critical thinking skills are needed, especially the speaking skills in the advanced course. The strategies for learning to speak, such as in speaking class required that students must be able to express, among others: (1) using concepts that have been learned, (2) developing critical thinking skills, (3) listen carefully to the opinions of others, (4) can communicate effectively with others, (5) recognize the problems that are around, (6) able to use the ability to solve problems or problem-solving skills, (7) change their confidence also attitude, (8) students are able to evaluate their ideas and attitudes, (9) develop interpersonal skills, (10) effectively participate in their group activities, and (11) students are able to think critically about various thoughts. Even this theory suggests a student's speaking ability, also assessed from the student's critical thinking ability (see Sejnost and Thiese, 2010: 91-93) in Ref. [3].

\subsection{Point Counterpoint Method}

The method "Point Counterpoint" was first developed by RoGERs in 1990 in Ref. [4] as a way or strategy to help students in developing their interpretation ability of a story, instead of relying on conventional explanation or relying on teacher's views. According to RoGERs, students need to practice their dealing skills with the intricacies of complex narratives. Students must learn to interpret textual information and use highly textual sources to describe their thoughts (Sejnost and Thiese, 2010: 68) in Ref. [5]. For that reason, in learning foreign languages like German, teachers are always challenged to teach with creative learning methods, so that they can achieve what we call learning objectives. In addition, the answers to various obstacles or shortcomings related to the final results achieved by students are also varying, including student competency itself. However, the final results of student learning are manifested through final grades; passing or whether not passing a particular course, including speaking skill or the ability to speak or communicate. Thus, the method "Point 
Counterpoint" is accepted as one solution. The contradicting information can be presented in helping students to develop their critical thinking skills. Jones (1992) in Ref. [6] notes that critical thinking is an alternative to make decisions with "blind acceptance", impulses, or attitudes and habits that involve the ability to explore and develop alternative imaginations. The "Point Counterpoint" method can be used as a teaching technique that aims to achieve this goal (Boggs \& Chatfield, 1995) in Ref. [7]. Further, the "Point Counterpoint" is not like a "60 minute" segment which generally follows the debate format and does not attempt to imply a winner or loser, or even a best answer. On the contrary, "Point Counterpoint" aims to present statements that appear to be contradictory, when it is viewed or analyzed in depth may both be instructive and appropriate perspectives [7].

Moreover, "Point Counterpoint" is a strategy to encourage students actively and positively in groups, so that they can exchange ideas and encourage students to optimize their potential, stimulate active discussion and debate. Thus, the students can get a deeper understanding. This method is an active learning method, which relies on group collaboration to obtain success in learning. In addition, the "Point Counterpoint" method is used to stimulate discussion, as well as to gain an in-depth understanding of various complex issues. This method requires that each group has a different perspective than the one discussed, so that each group must be able to defend their arguments, so they don't lose to other groups [8].

\subsection{Steps in Implementing the "Point Counterpoint" Learning Method}

The application of this method can be adjusted to what Boggs and Chatfield did in their research. Boggs and Chatfield divided students into 2 different groups of universities, where the subject of the assignment was "diagnosing plant problems" to increase student involvement. "Point Counterpoint" is done without giving prior knowledge about the techniques to the two classes or groups earlier. The class format involves the introduction of guest speakers (one of whom is a writer / researcher) who pursues the whole topic by using question quizzes. The "multifaceted" answer follows a predetermined script, another researcher asks to be introduced, then makes a counter (Counterpoint). The two researchers then pursued various angles or aspects of the question. More importantly, students are permitted and encouraged to participate. The conclusion for each class involves, letting students know that the exercise was prearranged and then spending time carefully according to the time given for each question, which aims to emphasize various critical thinking strategies. The following procedure steps that must be performed in implementing the method as Zaini in Handayani (2017) proposed are (1) choosing a problem or topic that has two or more perspectives; (2) Divide students into groups according to the number of perspectives that have been set; (3) Asking each group to reveal, discuss the reasons for different points of view; (4) Gathering other students and asking to sit close to the group; (5) Starting the debate by inviting which electives will start; (6) Asking for a response after one person has submitted their opinion; (7) 
Continue this process until the specified time; (8) Summarize the debate summary of the arguments that have been submitted.

Further, Sejnost and Thiese (2010: 68-69) in Ref. [9] suggested the 3 levels of strategic steps in implementing the "Point Counterpoint", namely: (1) Initial Responses to the story, which requires students response a story, or a given text. At this stage, for example, students read the texts or questions, and then record all ideas that come up to help them understand and interpret texts. In addition, they can use ideas related to characters, settings and plots, or text-related questions. (2) Discussion of responses, or answers, this requires students share their responses in class and they are encouraged to listen to the interpretive views or criticisms from other friends. Students must be prepared themselves to argue and defend their own ideas or views, and be able to openly understand various critical interpretations. On this stage, teacher or instructor must react as a facilitator. (3) Development of final responses, or final answers. Ideally, the intended response is their own judgment regarding their ideas, or interpretation of a given literature study and differing views. Furthermore, RoGERs implemented the "Point Counterpoint" strategy at the advanced level students. It adapted to a number of other strategies, including responding selection with sketches, using Venn diagrams to compare various views or aspects, made in the form of debate, and writing a group essay, skit (drama) or dialogue. For that reason, this research will be conducted in the form of discussion or debate, the form and steps will be adapted from R.G. Meyer and Southern Regional ETTC (see Sejnost and Thiese, 2010: 70) in Ref. [9].

\subsection{The Advantages and Disadvantages of the Point Counterpoint Method}

The advantages and disadvantages of this method are adapted from Ref. [10]. Through discussion will sharpen the results of the conversation or debate, students can be stimulated to analyze the problem or issue given, students can convey facts from various aspects of the problem, then critically examine or analyze facts that can be scientifically justified, provide interest and interest between groups so other students can also talk and participate in conveying ideas. Furthermore, the issue of discussion or debate is able to maintain student interest and continue to follow the contents and this strategy can be applied to large groups. Furthermore, Boggs and Chatfield [7] revealed the advantages of this method that based on an evaluation of how this exercise was successful. This method is a very effective form of teaching in presenting various problems. This method is considered to provoke and lead to more active student participation, and this is the best method or a good way to understand the problem given [7]. While, the disadvantage of the "Point Counterpoint" Learning Method, as in a discussion or debate there must be a strong will of each participant or group to win. There is possibility of a negative impression between groups will appear on a particular issue debate, emotional will emerge and there will be a lot of emotions involved, and requires extra and thorough preparation beforehand. 


\section{Research Method}

Class Action Research (CAR) method is applied in accordance with the procedure of class action research, which is conducted in a cycle process. The procedure consists of the action planning, observation and reflection. The CAR is a spiral self-reflection cycle in order to make the process of improving the faced conditions, and to find solutions in solving problems. Further, this is implied in order to find the new ways that are better and more effective for achieve more optimal results (Kemmis S. and M.C. Tanggrat in Karniti, 2002: 15) in Ref. [11]. The research subjects were 30 students of the German Language Study Program of the $5^{\text {th }}$ semester, whom are chosen based on the indicated problems as described in the introduction. The valued points in this classroom action research are the activeness of students in learning, the learning result, and the student's response to the learning process of German advanced courses during applying the "Point Conterpoint" method. While the research instruments used are (1) the language test or speaking test (presentation and discussion) at the B1 German language level, and (2) the non-test (student observation sheets) about all the process. The data collected is analyzed using the descriptive analysis. The data analysis is done to look for the level of activeness, the average or Mean (M), learning result, and successful of mastery speaking [12]. The results are then converted to the five-scale as shown in the following Table 1.
Table 1. 5 Scale Criterion of Referenced Assessment.

\begin{tabular}{|l|l|l|}
\hline Percentage & $\begin{array}{l}\text { Criteria of Learning } \\
\text { Result }\end{array}$ & $\begin{array}{l}\text { Process of Learning German Subject } \\
\text { Aufbaustuffe"/Advanced course }\end{array}$ \\
\hline $90-100$ & very high/excellent & extremely active \\
\hline $80-89$ & high & (somewhat) active \\
\hline $65-79$ & moderate/significant & average active \\
\hline $55-64$ & low & somewhat inactive \\
\hline $0-54$ & very low/none & extremely inactive \\
\hline
\end{tabular}

\section{Results and Discussion}

It has been explained in the previous chapter that this research is a class action research, which is planned to be carried out for two cycles. Each cycle taken place in three meetings. The quantitative data are gained through the oral test results in the first cycle, which includes 3 forms of tasks by referring to 4 criteria established by the Common European Framework. Overall, the average student's achievement test of first cycle is $15.58+23.16$ $+8.19+12=58.93$. The average score obtained by students for the first cycle test can be clearly seen in the Fig. 1.

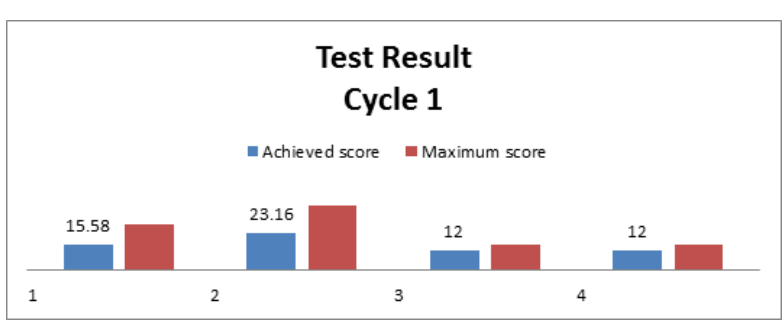

Figure 1. Test Result of First Cycle.

This figure explains that overall student achievement on the first cycle test has not yet reached a minimum score or passing grade according to the provisions of $65 \%$ of the total score $(100)=65$. The conclusion is confirmed 
through the notes of observation during the learning activities. The observation gives some notices, among others (1) working in small groups provides equal opportunities for all group participants to be active in group work and at presentations; (2) group work can provide opportunities for the students with weakness to be active in accordance with the dynamics of the group. In this case, the principle of peer tutoring is created; (3) the students have shown their performance in expressing opinions, counter opinion or giving feedback, also suggestions using good German, but there are some things that need to be improved. Students need extra practice time, especially in the presentation phase, because students are still not familiar with a good presentation format. This affects not only the use of utterances, but it affects also the student's actions and reactions to the presentation theme; (4) the lecturer could not be patient in doing direct feedback; (5) students were nervous during presentation, (6) lack of time preparation, (7) students have difficulties in giving feedback regarding discussed issues, and having problem in using the right of German structures.

Further, the average student achievement test at the second cycle is $21+27.4+12.1+12$ $=72.5$. More clearly could be seen in the following Fig. 2.

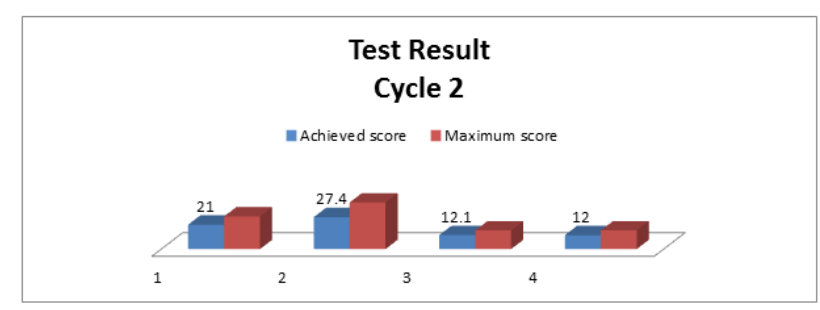

Figure 2. The Average Test Result of Cycle 1 and Cycle 2.
The Fig. 2 above explains that overall student achievement on the second cycle test has exceeded the minimum score or passing grade according to the provisions of $65 \%$ of the total score $(100)=65$. The conclusion is confirmed through observational notes during the learning activities taken place. The observation notices were followed as the notice on the first cycle, some changes were; (1) Students were still nervous in their performance of delivering presentation; (2) Lecturers didn't interrupt the conversation, or not doing direct correction, so that the discussion were not disrupted and students were more focused on the discussion; (4) The preparation time is sufficient; (5) the use of mind-mapping, video and guided questions can broaden the horizons of students' thinking; (6) German structure and student's vocabulary were still need to be considered and corrected after learning, because it was the fundamental mistakes are found. The notes about student's mistakes during the discussion were the misused of preposition, cases, tenses and conjugations verb.

The average student achievement test in the first and the second cycle shows a significant difference as described above. In the first cycle test, students reached an average score of 58.93. Figure 1 which shown the result 58.93 provides an explanation that students have not met the passing criteria as explained earlier, because these results are still far from the minimum score that must be achieved (passing grade) which is $65 \%$ of the score maximum (100) is $65 \% \times 100=65$. While the results of the second cycle test show that the average score of students after completing the three stages of the test is 72.5. In other word, there was an increase 
of 13.57 score. It can clearly be seen in the following diagram:

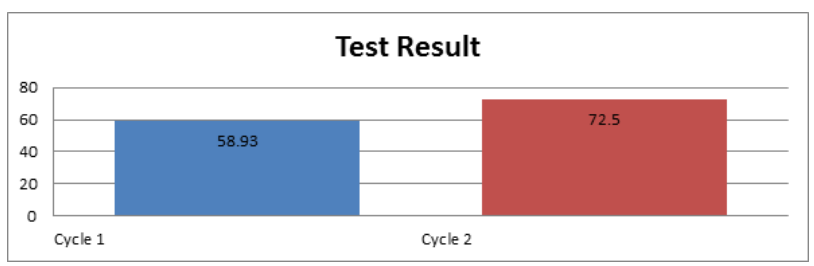

Figure 3. The Average Test Result of Cycle 1 and Cycle 2.

The score 72.5 explains that students have met the passing grade or the criteria, because 72.5 has exceeded the minimum number that must be achieved as the passing grade as mentioned above, namely 65 . This means that corrective action is based on the results of evaluation and reflection in the first cycle, which applied during the second cycle, has succeeded in improving students' speaking ability, including in planning an activity, to present a theme and in a question and answer. Instead, there are still a number of things that need to pay attention, such as feeling nervous in discussions. This shows that students has focused on the use of language appropriately, instead also focused on the ideas or content of the conversation that must be conveyed.

Moreover, Lai-Mei Leong \& Seyedeh Masoumeh Ahmadi in the International Journal of English Education (2017: 36) in Ref. [13] suggested the one speaking challenge in learning is that "They are worried about making mistakes and fearful of criticism. They are ashamed of the other students' attention towards themselves". Students have a feeling of worried, ashamed, afraid if making mistakes and fearful of criticism. Further, the adequate time and insight, vocabulary and appropriate topics are important things that lecturer has to pay attention. A suitability of the conversation theme in accordance with the interests of students can enable them to speak, because they already have a schemata or positive structure about the theme. Those things as emphasized by Lai-Mei Leong \& Seyedeh Masoumeh Ahmadi in Ref. [13] that "learners complain that they cannot remember anything to say and they do not have any motivation to express themselves". The suggestion above and findings compromised two important things; mental or psychological and teaching material. About mental, students need to be strengthened through creating the educative learning atmosphere, thus any student who makes mistake must still getting support from both lecturers and other students. Based on the observation notices, lecturers' should find a good comfortable way to make corrections in order to reduce or even eliminate the student's fear and intimidated feeling. This proven regarding students' speaking behavior in the first cycle and the second cycle. The implementation of the improvements and adjustments in the second cycle was based on the reflection of the weakness of point counterpoint steps in the first cycle. Thus, it made a significant contribution such as the student's creative thinking without lecturer's intervention on the speaking process. Lecturer let students speaking freely, this enables students to be calmer and focus on developing their speaking potential. Moreover, students could think and speaking freely has been supported also by the choosing of the relevant discussion topic due to student's experience, knowledge and interests. Furthermore, choosing the relevant topic enabled students to be active in giving responses or ideas, because they already have insight, 
experience or schemata about the conversation theme.

\section{Conclusion}

Based on the above description and discussion, several conclusions can be made as follows: The use of the point counterpoint method can improve students' speaking abilities. This proven by the results of the second cycle test, which shows an increase in speaking ability compared to the test results in the first cycle. Besides, the use of the point counterpoint method can improve student's creative thinking skills, especially in argumentation; if it is done in apart from the lecturer's intervention, especially in the form of direct correction or feedback. The implementation of point counterpoint steps in learning German has strongly supported the achievement of speaking competence, especially at the B1-GER level. However, the format of the exam at the B1 level requires the ability to argue and how to argue is possible through the point counterpoint method.

This method is highly recommended for speaking comprehension class. Instead, the weaknesses of this method are confirming that it is not applicable for beginner language learners, for example at A1 level. The reason is the limitation in using vocabulary and grammar at the productive level. Further, this method cannot be accessed directly on the improvement of grammatical ability, because the application of this method is on the stage of using language, not the grammar improvement. Therefore, if there are misused of grammar during the discussion due to the low grammatical ability, it cannot be overcome at the same time. However, it must be combined with other subjects such structure class.

\section{Acknowledgement}

All authors thank to Rector of Pattimura University, Ambon-Indonesia especially to his dean in Faculty of Education and Teacher Training (FKIP) for their financial support under the Faculty's Grant of Research in 2019.

\section{Conflict of Interest Statement}

All the authors declare that they have no any conflict in their works both financial and ideas.

References

[1]. Eskey, D.E.. Reading Theoretical Foundation (in Teaching Second Language: Reading For Academic Purposes. Edison Wesley Publication Company (1986).

[2]. Khan, Jeannine. Mehrsprachigkeit, Sprachkompetenz und Schulerfolg: Kontexteinflüsse auf die schulsprachliche Entwicklung Ein-und Mehrsprachiger. Springer Fachmedien Wiesbaden GmBh (2018).

[3]. Sejnost, Roberta L. \& Thiese, Sharon, M. Building Content Literacy: Strategies for the Adolescent Learner. United State of America: Corwin A SAGE Ltd.(2010).

[4]. The content is in Ref. [4]. (Sejnost dan Thiese, 2010: 68).

[5]. Sejnost, Roberta L. \& Thiese, Sharon, M. Building Content Literacy: Strategies for the Adolescent Learner. United State of America: Corwin A SAGE Ltd. (2010).

[6]. The content is in Ref. [7]. Boggs (Boggs \& Chatfield, 1995).

[7]. Boggs, Joseph F. \& Chatfield, James. Point - Counterpoint : A Method for Teaching Critical Thinking. Journal of Extension 33(4), (1995).

[8]. Handayani, Elfira. Pengaruh Strategi Pembelajaran Aktif Tipe Point Counterpoint Menggunakan Poster Session Terhadap Hasil Belajar Biologi Siswa Kelas X SMA Negeri 3 Bulukumba. Skripsi. Universitas Islam Negeri Alauddin, Makassar. (2017). 
[9]._The content is in Ref. [5] (Sejnost, Roberta L. \& Thiese, Sharon, M. Building Content Literacy: Strategies for the Adolescent Learner. United State of America: Corwin A SAGE Ltd., p. 68-70) (2010).

[10]. Handayani, Elfira. Pengaruh Strategi Pembelajaran Aktif Tipe Point Counterpoint Menggunakan Poster Session Terhadap Hasil Belajar Biologi Siswa Kelas X SMA Negeri 3 Bulukumba. Skripsi. Universitas Islam Negeri Alauddin, Makassar. (2017).

[11]. Kemmis Stephen, Robin McTaggart. The Action Research Planner. Doing Critical Participatory Action Research. Springer Singapore, Heidelberg, New York, p. 15 (2014).

[12]. Nurkancana, Wayan \& P.P.N Sunartana, Evaluasi Pendidikan. Surabaya: Usaha Nasional, p. 174 (2002).

[13]. Leong, Lai-Mei \& Ahmadi, Seyedeh Masoumeh. (2017). An Analysis of Factors Influencing Learners' English Speaking Skill. International Journal of Research in English Education , p. 36 (2017). Online source: http://ijreeonline.com/article-1-38-en.pdf. Page 34-41

[14]. Funk Hermann, Kuhn Christina, Skiba Dirk, Dorothea Spaniel-Weise, Rainer Wicke. Aufgaben, Übungen, Interaktion. München : Goethe Institut, Langenscheid, Klett Verlag. (2014).

[15]. Cottrell, Stella. Critical Thinking Skills: Developing Effective Analysis and Argument. Palgrave Macmillan (2005).

[16]. Sejnost, Roberta L. \& Thiese, Sharon, M. Building Content Literacy: Strategies for the Adolescent Learner. United State of America: Corwin A SAGE Ltd. (2010).

[17]. Nunan, David. Language Teaching Methodology. New York: Prentice Hall, 1991.

[18]. ------Second Language teaching \& Learning. New York : Heinle Heinle Publishers. (1999),

[19]. ----- Research Method in Language Learning. Cambridge : Cambridge Uni Press, (1997).
${ }^{+} \mathrm{A}$ Brief $\mathrm{CV}$ of Corresponding author:

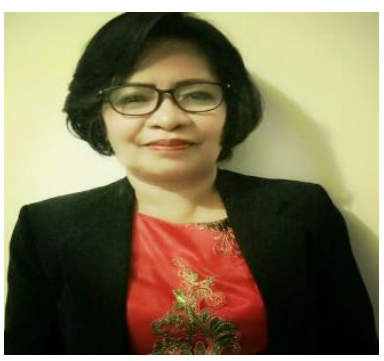

Dra. Henderika Serpara, M.Pd, born in Usliapan, in Central Moluccas, Maluku Province on February $5^{\text {th }}$, 1966. Graduated with a Bachelor of Teacher Training and Educational Science (S1) at Pattimura University in 1990. In 1998 completed a Master Degree Program (S2) in the Program Magister of Educational Science of IKIP in Jakarta with the main specification of study in German Language Teaching. Since 1992 the present author is a Lecturer on the German Language Study Study Program at Teacher Training and Educational Sciences Faculty of Pattimura University. The courses taken are teaching German methods, German studies, linguistic and didactic. The research that has been done by Henderika Serpara are : Super learning method as a strategy learning and teaching German language, Journal of ILPEN Vol. 1, No. 03, December 2003; "Sprachlernspiele fuer DAF", Journal of Innovation of learning (INOPSTEK), Vol. 2, No. 1, January 2009; Improving of the Listening Competency of German, Journal of Logika, Vol. 7, No. 1, May 2009; The Effectively Global Method to Improve Students language ability, Journal of INOPSTEK, Vol. 3, No. 1, January 2010; Influence of implementation the Real Things Media toward the Learning Result of Writing skills, Journal of Tahuri, Pg. 61-62; The Correlation between Student's Motivation to learn German and reading skills, Journal of INOPSTEK, Pg. 6-10; Using of Concept Sentence Method in Learning and teaching of Writing skills, Journal of Tahuri, Pg. 81-89; The effort of improving speaking skills of German Student's through Inside Outside Circle Method, Journal of Tahuri, Pg. 42-49. 